University of South Florida

DIGITAL COMMONS

Digital Commons @ University of

@ UNIVERSITY OF SOUTH FLORIDA

South Florida

8-1984

\title{
Seasonal Adjustments in the Equatorial Atlantic during 1983 as Seen by Surface Moorings
}

Robert H. Weisberg

North Carolina State University at Raleigh, weisberg@marine.usf.edu

Follow this and additional works at: https://digitalcommons.usf.edu/msc_facpub

\section{Scholar Commons Citation}

Weisberg, Robert H., "Seasonal Adjustments in the Equatorial Atlantic during 1983 as Seen by Surface Moorings" (1984). Marine Science Faculty Publications. 399.

https://digitalcommons.usf.edu/msc_facpub/399

This Article is brought to you for free and open access by the College of Marine Science at Digital Commons @ University of South Florida. It has been accepted for inclusion in Marine Science Faculty Publications by an authorized administrator of Digital Commons @ University of South Florida. For more information, please contact digitalcommons@usf.edu. 
Abstract. Upper ocean seasonal variations in velocity and temperature observed with current meters on surtace moorings along the equator in the Atlantic during February - September 1983 are shown. The longitudinal variation in the duration of upwelling and downwelling responses to zonal wind stress changes are discussed. These responses exhibit an integral character dependent upon longitudinal position which is consistent with forced linear long wave theory.

\section{Introduction}

During the first year of the SEQUAL/FOCAL experiment a seven element surface moored current meter array was in place with moorings along the equator near $4^{\circ} \mathrm{W}, 15^{\circ} \mathrm{W}, 24^{\circ} \mathrm{W}$, and $28^{\circ} \mathrm{W}$ and with moorings along $28^{\circ} \mathrm{W}$ near $0^{\circ} 45^{\prime} \mathrm{S}, 0^{\circ} 44^{\circ} \mathrm{N}$, and $6^{\circ} \mathrm{N}$. Data from $6^{\circ} \mathrm{N}$ are discussed by Richardson (1984) and data from $4^{\circ} \mathrm{W}$ are being prepared by colin (personal communication). Here we will consider the seasonal scale variability observed along the equator between $28^{\circ} \mathrm{W}$ and $15^{\circ} \mathrm{W}$ over the period February-September 1983. Reference is made to Welsberg (1984) for locations and instrument depths.

Seasonal variations in the horizontal velocity components and temperature are in response primarily to the zonal component of wind stress $\left(\tau^{x}\right)$ which was observed at $4^{\circ} \mathrm{W}$ (Colin, personal communfcation), $15^{\circ} \mathrm{W}$ and $24^{\circ} \mathrm{W}$ (Payne, 1984) and $29^{\circ} \mathrm{W}$ (Garzoli and Katz, 1984). Features germane to the present paper are that $\tau^{X}$ relaxed at all of these locations during late March and then increased over approximately one month beginning early in April. This relaxation and subsequent intensification occurred nearly simultaneously across the basin with the $4^{\circ} \mathrm{W}$ location leading the $29^{\circ} \mathrm{W}$ location by roughly one week. Although the detalls may vary from year to year these general features constitute a regular part of the equatorial trade wind seasonal cycle as shown by Garzol1 and Katz (1984). The upper ocean response as seen by moored current meters will now be presented in light of the observed winds.

\section{Surface Current Development}

The equatorial surface flow associated with the South Equatorial Current (SEC) has its maximum speed between $1^{\circ} \mathrm{N}-2^{\circ} \mathrm{N}$, e.g., Richardson and McKee (1984). Figure 1 shows low pass filtered east $(u)$ and north $(v)$ velocity components from the 10m level at $0^{\circ} 44^{\prime} \mathrm{N}, 28^{\circ} 11^{\prime} \mathrm{W}$. During March the surface flow was sluggish. It then accelerated westward in response to the wind stress intensification and a similar eastward acceleration was observed in the North Equatorial Countercur-

Copyright 1984 by the American Geophysical Union.

Paper number 4L6109.

0094-8276/84/004L-6109\$03.00 rent (NECC) at $6^{\circ} \mathrm{N}$ by Richardson (1984). Following the development of the SEC/NECC system was the generation of a wave packet clearly observed in v. The packet existed for $2-3$ cycles during which the surface currents decelerated. Weisberg (1984) discusses the phase and energy propagation of the wave packet which Philander (1978) has modelled in terms of barotropic instability.

\section{Variations Across the Thermocline at $28^{\circ} \mathrm{W}$}

Contour plots of the velocity components and temperature as a function of depth and time at the equatorial $28^{\circ} \mathrm{W}$ location are shown in Figures $2 a, b, c$. The wind relaxation event at the end of March resulted in a zonal transport pulse over the entire $200 \mathrm{~m}$ observational domain, a downwelling of the thermocline, and an increase in surface temperature. Although the wind stress increased immediately thereafter resulting in upwelling, it was not until 1-2 months later that the principal seasonal adjustment was observed. Mid-May through June was this transition period at $28^{\circ} \mathrm{W}$ during 1983 . The upper boundary of the $20 \mathrm{~cm} / \mathrm{sec}$ isotach which had encompassed the entire domain abruptly dropped to a depth of 25-50 $m$ with intermittant westward flow then appearing above that level. The depth of the Equatorial Undercurrent (EUC) core increased from $75 \mathrm{~m}$ to $100 \mathrm{~m}$ and the depth of the $15^{\circ} \mathrm{C}$ isotherm increased an equivalent amount effectively thickening the thermocline. Coincldent with these seasonal adjustments of the thermocline and the zonal velocity component was the onset of the wave packet observed in $v$. It appears that several physically distinct but interrelated processes occurred during this transitional period.

\section{Variations Along the Equator}

Since the relaxation and subsequent intensification of $\tau^{x}$ was observed at all of the equatorial measurement sites it would follow that the ocean's response at these sites should bear simi1arity. This is generally true but certain differentiating points, particularly at the surface and in the thermocline, warrant mention. Superimposed in Figure 3 are low pass filtered temperature time series from the equatorial $28^{\circ} \mathrm{W}$ and $15^{\circ} \mathrm{W}$ moorings. The top two are from the $10 \mathrm{~m}$ level while the bottom two are from $75 \mathrm{~m}$ at $28^{\circ} \mathrm{W}$ and $50 \mathrm{~m}$ at $15^{\circ} \mathrm{W}$. The shallower depth was chosen at $15^{\circ} \mathrm{W}$ since the thermocline shoals to the east along the equator.

The relaxation event marks the end of the low wind season. Well defined warming pulses appear at both the surface and thermocline levels with the surface pulse at $15^{\circ} \mathrm{W}$ leading that at $28^{\circ} \mathrm{W}$ by a few days. The pulse in the thermocline behaves differently. First, it lags the surface pulse by a few days consistent with Figure $2 b$ and $c$ where the overal1 temperature response lags $u$ as required to redistribute mass and heat, and 


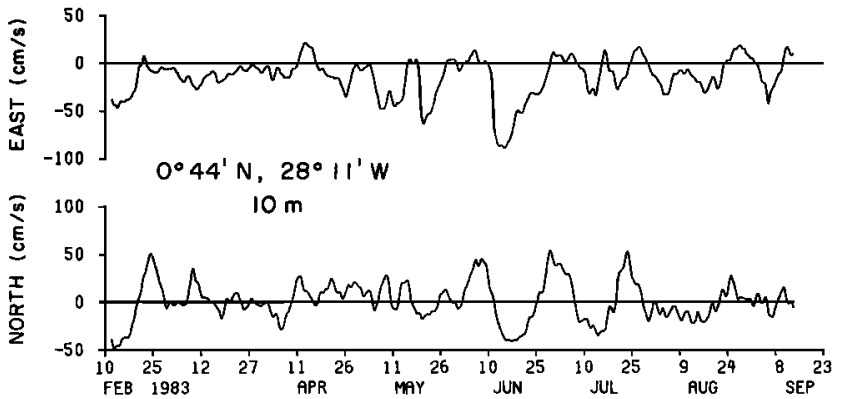

Fig. 1. Low pass filtered north and east velocity components from the $10 \mathrm{~m}$ level at $0^{\circ} 44^{\prime} \mathrm{N}$, $28^{\circ} 11^{\prime} \mathrm{W}$.

second, the pulse at $15^{\circ} \mathrm{W}$ occurs over a longer duration than at $28^{\circ} \mathrm{W}$ and with a second and larger peak.

Immediately following the relaxation, the zonal wind stress began to intensify during the first week in April and this was accompanied by an upwelling of the isotherms within the thermocline and a surface cooling. Although the cooling at the surface and thermocline levels began at approximately the same time and with the same rate at both longitudes, it proceeded for roughly twice as long at $15^{\circ} \mathrm{W}$ as at $28^{\circ} \mathrm{W}$ before giving way to downwelling. The same sequence of events (upwelling followed by downwelling) was observed at $24^{\circ} \mathrm{W}$ with the duration being intermediate between that observed at $28^{\circ} \mathrm{W}$ and $15^{\circ} \mathrm{W}$.

\section{Discussion}

The sequence of events which occurred within the thermocline are consistent with forced linear long wave responses to decreasing and increasing zonal wind stress. Consider first the downwelling of isotherms associated with the wind stress relaxation. Analytical and numerical model studies, e.g., Cane and Sarachik (1976) and Philander (1981), have shown that the oceanic zonal pressure gradient will begin to relax as an equatorial Kelvin wave upon removal of the wind stress. This forced response is an integral one, and since Kelvin wave characteristics run eastward, points farthest to the east within the forced region respond over the longest duration and consequently with the largest amplitude. The second peak at $15^{\circ} \mathrm{W}$ is more speculative. If the wind stress was larger in the western Atlantic as climatology would suggest then a second peak would appear as a relaxation pulse related to the larger zonal pressure gradient initially occurring in the west.

Next consider the effects of increasing easterlies. A forced upwelling Kelvin wave response will initially control the thermocline in the central portion of the basin. Again, since forced wave responses are integral ones, the upwelling at the easternmost point within the forced region will occur over the longest duration and with the largest amplitude. Boundary reflections of the forced responses (e.g., Cane and Sarachik, 1977 and Philander and Pacanowski, 1981) will then come into play as a downwelling Kelvin wave from the western boundary and an up-

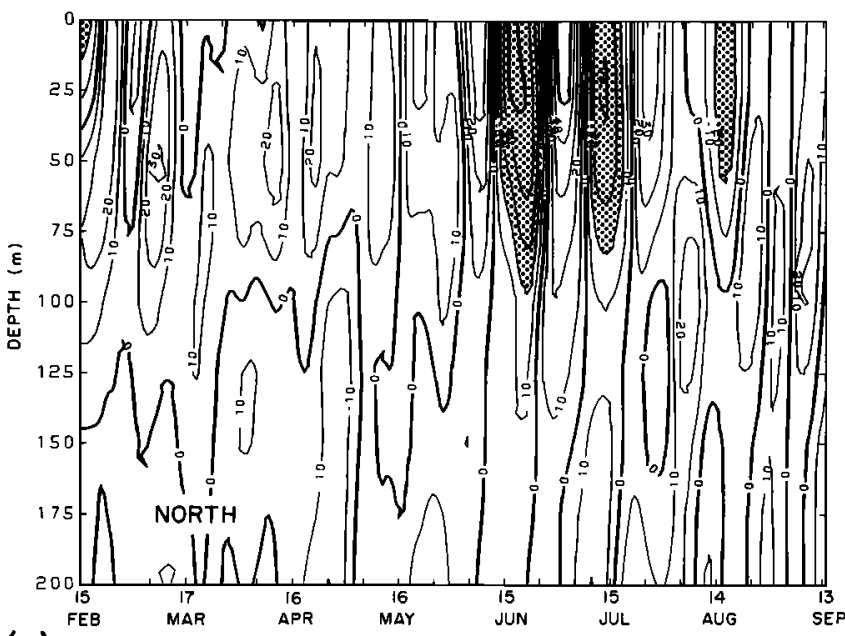

(a)

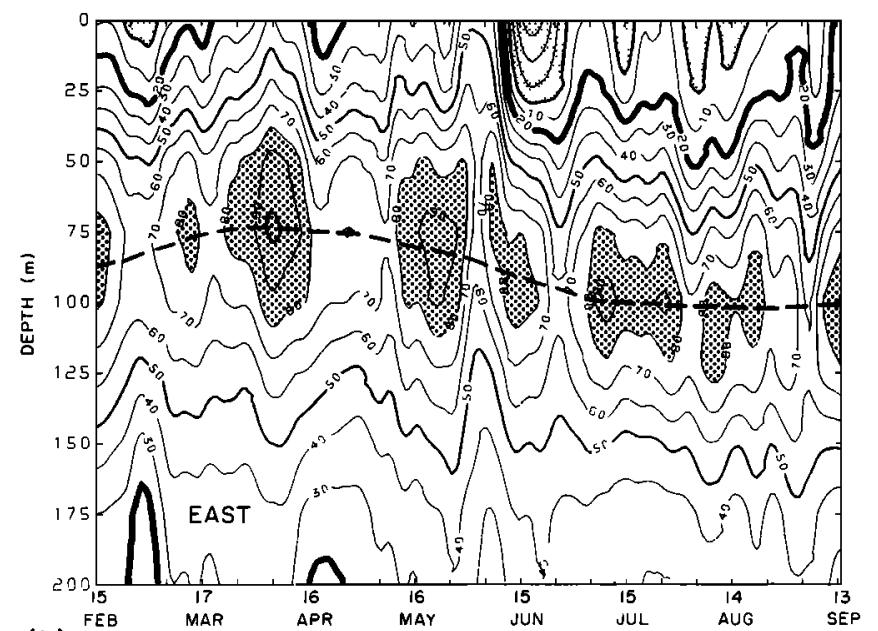

(b)

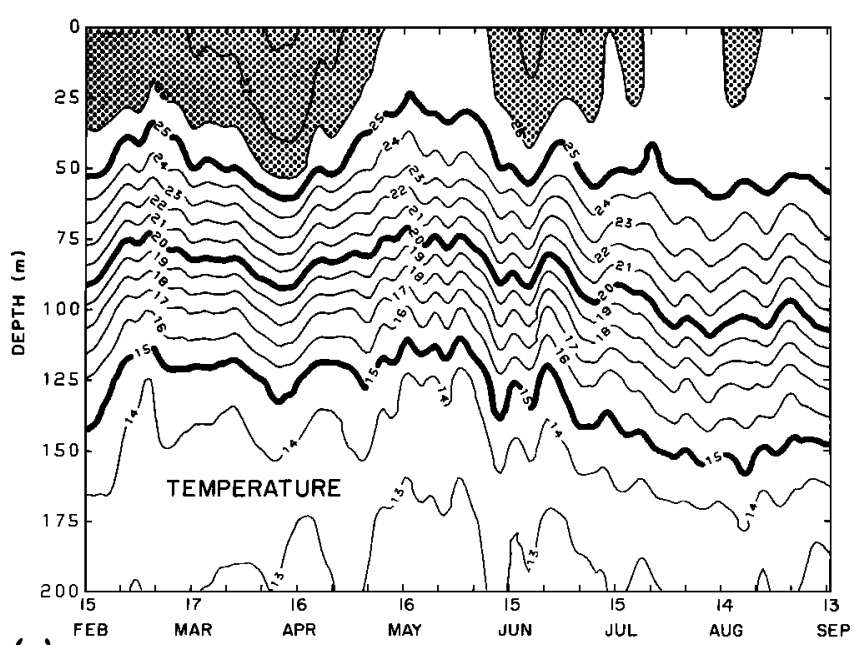

(c)

Fig. 2. Contour plots of the a) north and b) east velocity components, and c) temperature as a function of depth and time at $0^{\circ} 00^{\prime} \mathrm{N}, 28^{\circ} 09^{\prime} \mathrm{W}$. Measurement depths were at $10 \mathrm{~m}, 50 \mathrm{~m}, 75 \mathrm{~m}, 100 \mathrm{~m}$, $150 \mathrm{~m}$, and $200 \mathrm{~m}$. The dashed line in b approximates the core of the Equatorial Undercurrent. 


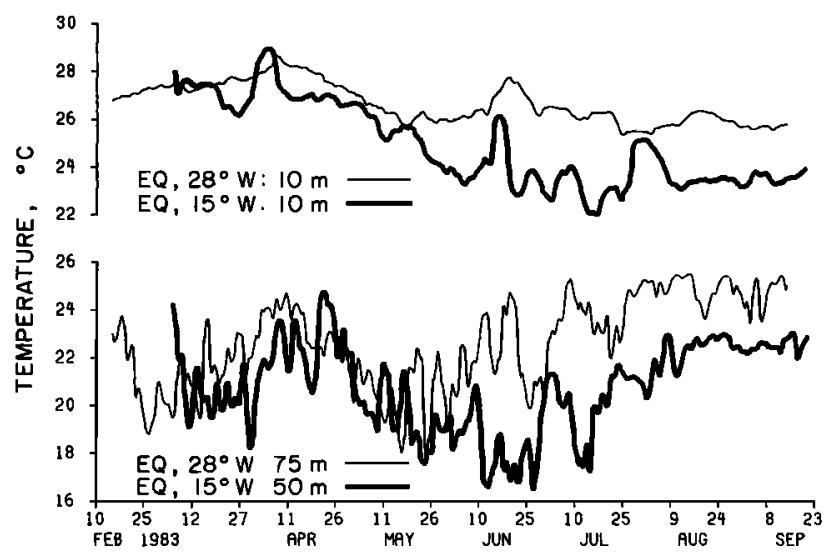

Fig. 3. Low pass filtered temperature time series from the equatorial $28^{\circ} \mathrm{W}$ and $15^{\circ} \mathrm{W}$ moorings. The upper time series are from $10 \mathrm{~m}$ and the lower time series are from $75 \mathrm{~m}$ at $28^{\circ} \mathrm{W}$ and $50 \mathrm{~m}$ at $15^{\circ} \mathrm{W}$.

welling Rossby wave from the eastern boundary. Their arrival times will depend upon longitudinal position. Boundary effects appear at $28^{\circ} \mathrm{W}$ toward the end of May when upwelling is replaced by downwelling, eventually leading to a seasonally adjusted steady state. At $15^{\circ} \mathrm{W}$ these boundary effects do not appear until the beginning of July at which time upwelling ceases and downwelling begins. Note that this upwelling/downwelling sequence is nearly symmetrical at both longltudes but that the $15^{\circ} \mathrm{W}$ longitude, being around twice the distance from the western boundary, has an overall sequence duration around twice that at $28^{\circ} \mathrm{W}$.

\section{Summary}

Data on the evolution of the horizontal velocity and temperature fields across the thermocline at $28^{\circ} \mathrm{W}$ and along the equator at $28^{\circ} \mathrm{W}, 24^{\circ} \mathrm{W}$ and $15^{\circ} \mathrm{W}$ have been presented in light of the observed zonal wind stress variability during February-September 1983. The principal features of the wind stress were a relaxation event immediately followed by a rapid seasonal increase in easterly stress. An eastward momentum surge and downwelling accompanied the relaxation event while the response to increased easterlies was an immediate upwelling followed progressively later to the east by a downwelling to a seasonally adjusted steady state.

It is paradoxical that both times of maximum downwelling occurred when the easterly winds were either seasonally weakest or strongest. This is consistent however with a forced linear response as is the period of upwelling which occurred in between. A forced Kelvin wave response to either decreasing or increasing easterlies is an integral one from the polnt of observation westward. Decreasing (increasing) easterlies results in downwelling (upwelling) with larger magnitude and duration to the east since the domain of integration is larger. Thus, one reason why $0^{\circ} \mathrm{W}-10^{\circ} \mathrm{W}$ along the equator in the Atlantic Ocean has historically been a region of maximum upwelling is because it is the origin of the easterly wind stress and therefore has the largest integral re- sponse (e.g. Weisberg and Tang, 1983). Boundaries come into play in signaling the end of the upwelling season. The forced response to increasing easterlies reflects at the western boundary as a downwelling Kelvin wave which upon reaching the observational point initiates a change to a new seasonally adjusted state. It follows that the overall temporal shape of the equatorial thermocline's seasonal variability should depend upon longitudinal position relative to both the zonal wind stress forcing and the meridional boundaries in a manner similar to what was observed.

Acknowledgements. Support was provided by the Oceanography Section, National Science Foundation, under Grant \#OCE-8211848. M. Cane, G. Philander, T.Y. Tang and T. Welngartner provided constructive discussions. J. Hickman and T. Clay assisted with computations and graphics.

\section{References}

Cane, M. and E. S. Sarachik, Forced baroclinic ocean motions. I. The linear equatorial unbounded case, J. Mar. Res., 34, 629-665, 1976.

Cane, M. and E. S. Sarachik, Forced baroclinic ocean motions. II. The linear equatorial bounded case, J. Mar. Res., 35, 395-432, 1977.

Garzoli, S. and E. J. Katz, Winds at St. Peter and St. Pauls rocks during the first SEQUAL year, Geophys. Res. Lett., (this issue), 1984 .

Payne, R., Surface Wind Measurements in SEQUAL I, Geophys. Res. Lett., (th1s issue), 1984.

Philander, S. G. H., Instabilities of equatorial currents, Part II, J. Geophys. Res., 83, 3679-3682, 1978 .

Philander, S. G. H., The response of equatorial oceans to a relaxation of the trade winds, J. Phys. Oceanogr., 11, 176-189, 1981 .

Philander, S. G. H. and R. C. Pacanowski, The generation and decay of equatorial currents, J. Geophys. Res., 85, 1123-1136, 1980.

Richardson, P. L., Moored current meter measurements in the Atlantic north Equatorial Countercurrent during 1983, Geophys. Res. Lett., (this issue), 1984.

Richardson, P. L., and T. K. McKee, Average seasonal variation of the Atlantic North Equatorial Countercurrent from ship drift data, J. Phys. Oceanogr., in press, 1984.

Welsberg, R. H., Instability waves observed on the equator during SEQUAL year one, to Geophys. Res. Lett., (this issue), 1984.

Weisberg, R. H. and T. Y. Tang, Equatorial ocean response to growing and moving wind systems with application to the Atlantic, J. Mar. Res., 41, 461-486, 1983.

R.H. Weisberg, Department of Marine, Earth and Atmospheric Sciences, North Carolina State University, Raleigh, NC 27695.

(Received March 8, 1984; accepted May 15, 1984.) 